\title{
Non Fossil H.G.I. CRADA Report CRADA PC90-001, Final Report
}

\author{
Colleen Butcher \\ Deborah Hreha \\ Thomas Beatty \\ Donald Kirkland
}

no date

(Submitted January 1999)

U.S. Department of Energy

Federal Energy Technology Center

P.O. Box 10940

626 Cochrans Mill Road

Pittsburgh, PA 15236-0940

and

American Society for Testing and Materials

100 Barharbor Drive

West Conshohocken, PA 19428-2959 


\section{NON FOSSIL H.G.I. CRADA REPORT}

Responsible Person: Colleen Butcher

Parson's Group Leader: Deborah Hreha

Parson's technician: Thomas Beatty

Parson's technician: Donald Kirkland

Location: HGI lab in NW corner of Bldg 83

CRADA Partner: ASTM

\begin{tabular}{|c|c|c|}
\hline Year & Samples Sold & Price \\
\hline 1993 & 95 & $\$ 250$ \\
\hline 1994 & 81 & $\$ 250$ \\
\hline 1995 & 51 & $\$ 500$ \\
\hline 1996 & 46 & $\$ 500$ \\
\hline 1997 & 58 & $\$ 500$ \\
\hline 1998 as of $11 / 2 / 98$ & 39 & $\$ 500$ \\
\hline Total= & $\mathbf{3 8 0}$ & $\$ 1 \mathbf{1 4 0 0 0}$ \\
\hline
\end{tabular}

The price of $\$ 500$ covered manufacturing for the past four years, not shipping. Before 1995 the HGI manufacturing and shipping was mostly subsidized by the government.

Semiannual ASTM D-05 committee meetings are attended by the responsible person in order to excahnge information. These are held at various locations throughout the US and Canada.

A set consists of 4 canisters, each of a different hardness: $40,60,80$ and 110 . The money the US DOE receives comes from the customer who wants to purchase the set. Customers consist primarily of domestic power utility companies and Commercial Laboratories. Countries we have shipped to include, but are not limited to, South Africa, Brazil, Chile, Peru, Indonesia, France, Germany, Australia, Japan, India, Canada and Switzerland.

Attached are the official ASTM procedures used in the production of the sets which are reviewed yearly by the ASTM D05 committee. The two Parson's technicians are trained in accordance with these procedures.

$$
\text { Qttachments copyrighted, therefare, not scanned. }
$$




\section{Disclaimer}

This report was prepared as an account of work sponsored by an agency of the United States Government. Neither the United States Government nor any agency thereof, nor any of their employees, makes any warranty, express or implied, or assumes any legal liability or responsibility for the accuracy, completeness, or usefulness of any information, apparatus, product, or process disclosed, or represents that its use would not infringe privately owned rights. Reference herein to any specific commercial product, process, or service by trade name, trademark, manufacturer, or otherwise does not necessarily constitute or imply its endorsement, recommendation, or favoring by the United States Government or any agency thereof. The views and opinions of authors expressed herein do not necessarily state or reflect those of the United States Government or any agency thereof. 


\section{DISCLAIMER}

Portions of this document may be illegible in electronic image products. Images are produced from the best available original document. 